\title{
EVALUASI PENGENDALIAN INTERN PADA SIKLUS PENGGAJIAN PT ANEKALOKA INDOTUNA DI BITUNG
}

\author{
Maria Marisa Marau \\ Grace B. Nangoi \\ Hendrik Manossoh
}

Fakultas Ekonomi dan Bisnis, Jurusan Akuntansi

Universitas Sam Ratulangi Manado

email: maria_marau@yahoo.co.id

\begin{abstract}
A company is considered successful if it can manage their payroll cycles. This is because the payroll can directly affect the performance of the employee. Companies must ensure the welfare of workers by giving them rights that salary in return for services rendered to the company's employees. Each activity requires a control of our lives to what is being and has been done. It is therefore necessary internal controls over payroll cycle at a company in terms of oversight of payroll. This study was conducted to determine and evaluate the Internal Control of Payroll Cyele in PT.Anekaloka Indotuna. The object of this research is PT.Anekaloka Indotuna Bitung, the company is engaged in the field of shipping and fisheries. The research method is qualitative method. The results showed that the internal control PT.Anekaloka payroll cycle has not completely efficient. Head of the company should increase the discipline monitor activity of employees.
\end{abstract}

\section{Keywords : evaluation, payroll, internal control}

\section{Latar Belakang}

\section{PENDAHULUAN}

Pada umumnya setiap perusahaan memiliki suatu sistem penggajian untuk mencapai tujuan perusahaan tersebut. Sistem di rancang untuk mencapai sesuatu yang berulangkali atau secara rutin terjadi, misalnya pemberian gaji pada karyawan. Setiap karyawan memiliki tugas dan tanggung jawab tertentu di dalam perusahaan tersebut dan mendapatkan gaji sesuai dengan pekerjaan yang mereka lakukan.

Pengendalian intern terkait dengan aspek yang ada dalam perusahaan, salah satu aspek tersebut adalah sistem akuntansi penggajian. Aspek ini menyangkut kesejahteraan sumber daya manusia merupakan perhatian yang serius, karena akan mempengaruhi prestasi dan semangat kerja karyawan.

Sebuah perusahaan dinilai berhasil apabila dapat mengelola siklus penggajiannya, oleh karena itu diperlukan pengendalian internal atas siklus penggajian pada sebuah perusahaan. Dengan adanya pengendalian intern siklus penggajian dapat mempengaruhi keberlangsungan operasional perusahaan serta produktivitasnya. Untuk itu pengendalian intern pada siklus penggajian perusahaan harus diterapakan untuk mengurangi kecurangan yang akan timbul.

\section{Tujuan Penelitian}

Adapun yang menjadi tujuan penelitian ini yaitu untuk mengetahui dan mengevaluasi Pengendalian Intern pada Siklus Penggajian PT. Anekaloka Indotuna Bitung.

\section{Pengertian Sistem}

\section{TINJAUAN PUSTAKA}

Menurut Azhar (2013:22) Sistem adalah kumpulan/group dari sub sistem/bagian/komponen apapun baik fisik ataupun non fisik yang saling berhubungan satu sama lain dan bekerja sama secara harmonis untuk mencapai satu tujuan tertentu. 


\section{Pengetian Akuntansi}

Menurut Bahati (2014), akuntansi adalah proses melalui mana informasi keuangan dicatat, terorganisir, diringkas, dianalisis, diinterpretasikan, dan dikomunikasikan. Ini berarti bahwa akuntansi berkaitan dengan desain sistem pencatatan organisasi, persiapan dokumen keuangan, analisis dan interpretasi dokumen keuangan.

\section{Pengertian Penggajian}

Menurut Nayla (2014:15), penggajian adalah suatu imbalan yang dibayarkan kepada

karyawan yang menjabat di perusahaan - perusahaan, mulai dari yang memegang jabatan paling tinggi hingga yang memegang jabatan paling rendah.

\section{Pengetian Sistem Akuntansi Penggajian}

Menurut Mulyadi (2015 : 309) mengemukakan bahwa sistem akuntansi penggajian adalah : Sistem akuntansi penggajian adalah fungsi, dokumen, catatan, dan sistem pengendalian intern yang digunakan untuk kepentingan harga pokok produk dan penyediaan informasi guna pengawasan biaya tenaga kerja.

Fungsi - Fungsi yang terkait

1. Fungsi Kepegawaian

2. Fungsi pencatat waktu

3. Fungsi pembuat daftar gaji

4. Fungsi akuntansi

5. Fungsi keuangan

\section{Dokumen - Dokumen yang digunakan}

Dokumen yang digunakan dalam sistem akuntansi pokok yang digunakan untuk melaksanakan penggajian yaitu:

1. Dokumen Pendukung Perubahan Gaji

2. Kartu Jam Hadir

3. Daftar Gaji

4. Rekap Daftar Gaji

5. Surat Pernyataan Gaji

6. Amplop Gaji

7. Bukti Kas Keluar

Catatan Akuntansi yang di gunakan

Catatan akuntansi yang di gunakan dalam Sistem Akuntansi Penggajian. Ada beberapa macam sistem pencatatan yang dapat digunakan:

1. Jurnal umum

2. Kartu biaya

3. Kartu penghasilan karyawan

\section{Sistem Pengendalian Intern}

Damayanti (2015), sistem pengendalian intern merupakan semua metode yang dapat digolongkan dalam subsistem pengendalian akuntansi dan administrasi, dimana perusahaan telah menggunakannya untuk mengendalikan jalannya perusahaan yang mencakup aktifitas pengamanan harta, memeriksa ketelitian data akuntansi dan administrasi, mendorong efisiensi operasi dan menjaga kebijaksanaan perusahaan dapat dipatuhi.

\section{Sistem Pengendalian Intern Menurut COSO}

Committee of Sponsoring Organization of the Treadway Commision (COSO) adalah proses dipengaruhi oleh dewan entitas direksi, manajemen dan personal lain, yang dirancang untuk memberikan keyakinan memadai tentang pencapaian tujuan dalam efektivitas dan efisiensi operasi, keandalan pelaporan keuangan dan kepatuhan terhadap hukum dan peraturan yang berlaku. Tujuan utama dari pengendalian internal adalah untuk membantu mengelola dan mengendalikan risiko secara tepat dan cermat.

lima komponen pengendalian internal menurut COSO di kutip oleh (Pratiwi, 2014) yaitu :

1. Lingkungan Pengendalian(Control Environment)

2. Penilaian Risiko (Risk Assessment)

3. Aktivitas Pengendalian (Control Activities)

4. Informasi dan komunikasi (Information and Communication)

5. Aktivitas Pemantauan (Monitoring Acivities) 


\section{Penelitian Terdahulu}

Herdyanto (2014) dalam penelitian yang berjudul Evaluasi Penerapan Pengendalian Internal Atas Siklus Penggajan pada PT. Jaya Kencana menyatakan dari penelitian ini dapat diperoleh bahwa hasil penelitian menunjukkan bahwa PT. Jaya Kencana memiliki pengendalian internal terhadap siklus penggajian yang baik, namun masih terdapat beberapa kelemahan-kelemahan yang ditemukan. Kelemahan yang masih ada dalam pengendalian internal perusahaan adalah terdapat potensi karyawan fiktif pada perusahaan dikarenakan banyaknya jumlah karyawan harian dalam suatu proyek dan masih belum ada sanksi yang tegas bagi karyawan yang terlambat masuk setelah jam makan siang.

\section{Jenis Penelitian}

\section{METODE PENELITIAN}

Jenis penelitian dalam penelitian ini adalah Penelitian Deskriptif dimana peneliti secara langsung mendatangi objek penelitian yaitu PT. Anekaloka Indotuna untuk memperoleh data-data dan informasi. Menurut Basirun (2010:5), penelitian deskriptif adalah salah satu jenis penelitian yang tujuannya untuk menyajikan gambaran cara sistematis dan akurat mengenai fakta, sifat dari hubungan antar fenomena yang diteliti pada suatu perusahaan.

\section{Tempat dan waktu penelitian}

Penelitian ini dilakukan di PT Anekaloka Bitung. Proses pengumpulan dan pengolahan data untuk penelitian ini memakan waktu selama 3 (tiga) bulan yang di mulai dari bulan januari 2016 sampai maret 2016.

\section{Prosedur Penelitian}

Prosedur penelitian yang akan di lakukan oleh penulis adalah sebagai berikut :

a. Perumusan masalah

Langkah pertama yang dilakukan adalah melihat dan mencari tahu inti permasalahan yang diangkat dan diteliti lebih lanjut.

b. Pengumpulan Data

Dalam tahapan pengumpulan data dilakukan dengan observasi langsung dan melakukan wawancara terhadap pihak-pihak yang ada di PT. Anekaloka Bitung.

c. Analisis Data

Setelah semua data-data diperlukan terkumpul, kemudian langkah selanjutnya dimulai dengan menganalisis data-data.

d. Penarikan Kesimpulan

Hasil data tersebut kemudian dipaparkan dalam bentuk uraian kalimat berupa keteranganketerangan yang terdapat dalam hasil penelitian dan pembahsan yang digunakan sebagai acuan dalam penarikan kesimpulan yang merupakan rangkuman dari keseluruhan penelitian ini.

\section{Metode Pengumpulan Data}

Metode data yang dikumpulkan dalam penelitian ini adalah data kualitatif. Menurut Soeratno (2010:64), data kualitatif ialah serangkaian observasi kemungkinnya tidak dapat dinyatakan dalam angka - angka.

Usaha untuk memperoleh data dan informasi yang berkaitan dengan penelitian ini serta sebagai bahan atau relevan evaluasi untuk keperluan pembahasan maka metode pengumpulan data yang di lakukan dengan cara :

\section{Observasi}

Obrservasi adalah proses pengamatan dan pencatatan secara sistematis mengenai gejalagejala yang di teliti. Observasi ini menjadi salah satu teknik pengumpulan data apa bila sesuai dengan tujuan penelitian yang di rencakan dan di catat secara sistematis.

\section{Wawancara}

Wawancara merupakan teknik pengumpulan data yang dilakukan melalui tatap muka dan tanya jawab langsung antara pengumpul data maupun peneliti terhadap nara sumber atau sumber data. Pihak - pihak yang di wawancara pada PT. Anekaloka Indotuna yaitu pimpinan perusahan dan karyawan bagian keuangan. 


\section{Metode Analisis}

Metode analisis data adalah suatu metode yang digunakan untuk mengelolah hasil penelitian guna memperoleh suatu kesimpulan. Dengan melihat kerangka pemikiran teoritis, maka teknik analisis data yang digunakan dalam penelitian ini analisis kualitatif, yaitu adalah data yang mencakup hampir semua data non-numerik. Data ini dapat menggunakan kata-kata untuk menggambarkan fakta dan fenomena yang diamati.

\section{Hasil Penelitian}

\section{HASIL PENELITIAN DAN PEMBAHASAN}

\section{Siklus Penggajian Pada PT. Anekaloka Indotuna}

PT. Anekaloka Indotuna menggunakan Siklus Penggajian dalam mengatur kegiatan perusahaan yang berkaitan dengan transaksi perhitungan dan pembayaran gaji karyawan. Adapun siklus penggajian PT. Anekaloka Indotuna yaitu : Gaji bulanan dalah sistem gaji yang diberikan kepada direktur, direktur personalia, pemasaran,semua divisi dan karyawan lainnya.

a. Fungsi terkait dalam siklus penggajian PT. Anekaloka Indotuna adalah sebagai berikut :

1) Fungsi kepegawaian

2) Fungsi pencatatan waktu hadir

3) Fungsi keuangan.

b. Dokumen yang digunakan dalam siklus penggajian PT. Anekaloka Indotuna

1. Kartu Kehadiran/Absensi

2. Daftar Gaji

3. Surat Pernyataan Gaji/Slip Gaji

\section{Prosedur Dalam Siklus Penggajian PT. Anekaloka Indotuna}

Jaringan prosedur yang membentuk siklus penggajian PT. Anekaloka, yang merupakan tahapan yang harus dilalui untuk menjamin terdapatnya transaksi yang aman dari kesalahan pencatatan waktu hadir, prosedur pembuatan daftar gaji, prosedur pembayaran gaji.

1) Prosedur Pencatatan Daftar Hadir

a. Setiap karyawan yang telah didata mengambil kartu absen masing - masing pada rak yang telah tersedia dan biasanya terletak dekat dengan mesin absensi kartu itu sendiri. Kemudian karyawan memasukkan kartu yang telah diambilnya ke slot mesin absensi dan kemudian kartu tersebut akan keluar.

b. Pada kartu yang telah dikeluarkan dari mesin absensi itulah tertera keterangan tentang waktu karyawan masuk dan pulang kerja, lalu kartu tersebut di letakkan di rak yang telah tersedia dan kemudian akan di data dan di proses lebih lanjut untuk membuat daftar kehadiran karyawan.

c. Apabila karyawan memasukkan kartunya tidak tepat pada waktunya, maka mesin absensi tersebut akan mencetak keterangan dengan menggunakan tinta merah sebagai tanda bahawa ia telat. Kartu yang terbuat dari kertas tebal itu merupakan media untuk mendata kehadiran masing - masing karyawan.

2) Prosedur Pembuatan Daftar Gaji

Prosedur ini adalah untuk membuat daftar gaji dalam rangka pembayaran gaji. Dalam daftar gaji dicantumkan penghasilan karyawan yang terdiri dari gaji pokok, lembur, insentif yang di terima..

3) Prosedur Pembayaran Gaji

Prosedur pembayaran gaji PT. Anekeloka Indotuna dilakukan secara manual oleh bagian keuangan. Dimana setiap daftar gaji yang telah berhasil di buat/direkap harus diperiksa terlebih dahulu oleh manager dan setelah selesai langsung dibawa pada bagian keuangan.

\section{Pembahasan}

\section{Evaluasi Pengendalian Intern Siklus Penggajian PT. Anekaloka Indotuna berdasrkan 5 komponen COSO :}

Untuk mengevaluasi pengendalian internal atas siklus penggajian pada PT Anekaloka Indotuna menggunakan pendekatan COSO yang terdiri dari 5 (lima) komponen. Berikut ini dijabarkan satu-persatu hasil dari evaluasi pengendalian internal : 
Tabel 1. Penilaian Lingkungan Pengendalian

\begin{tabular}{|l|c|c|c|}
\hline $\begin{array}{l}\text { Lingkungan } \\
\text { Pengendalian }\end{array}$ & Sudah & Belum & \multicolumn{1}{c|}{ Keterangan } \\
\hline $\begin{array}{l}\text { Integritas dan nilai etika } \\
\text { organisasi. }\end{array}$ & $\checkmark$ & & $-\begin{array}{l}\text { Sikap manajer yang berkaitan dengan penggajian } \\
\text { sudah cukup baik dalam menanggapi keluhan dan } \\
\text { menjelaskan kewajiban dan hak karyawan. }\end{array}$ \\
\hline
\end{tabular}

Tabel 2. Penilaian Penaksiran Risiko

\begin{tabular}{|l|l|l|l|}
\hline Penaksiran Risiko & Sudah & Belum & \multicolumn{1}{c|}{ Keterangan } \\
\hline $\begin{array}{l}\text { Organisasi menetapkan } \\
\text { tujuan dengan kejelasan }\end{array}$ & & $\checkmark$ & $\begin{array}{l}\text { Perusahaan belum menetapkan suatu tujuan dengan } \\
\text { kejelasan yang cukup. Pada Bagian keuangan yang } \\
\text { yang cukup untuk } \\
\text { memungkinkan identifikasi }\end{array}$ \\
$\begin{array}{l}\text { dan penilaian risiko yang } \\
\text { berkaitan dengan tujuan }\end{array}$ & & & $\begin{array}{l}\text { menghitung gaji karyawan lalu membagikan gaji } \\
\text { karyawan. }\end{array}$ \\
\hline
\end{tabular}

Tabel 3. Penilaian Aktivitas Pengendalian

\begin{tabular}{|c|c|c|c|}
\hline Aktivitas Pengendalian & Sudah & Belum & Keterangan \\
\hline $\begin{array}{lr}\text { Organisasi memilih dan } \\
\text { mengembangkan aktivitas } \\
\text { pengendalian } r \text { yang } \\
\text { berkontribusi terhadap } \\
\text { mitigasi risiko pencapaian } \\
\text { sasaran pada tingkat yang } \\
\text { dapat diterima. }\end{array}$ & & $\checkmark$ & $\begin{array}{l}\text { Perusahaan masih terdapat perangkapan fungsi dan } \\
\text { tugas serta wewenang yang masih belum jelas. } \\
\text { Misalnya pada bagian keuangan yang masih } \\
\text { merangkap sebagai bagian penggajian. }\end{array}$ \\
\hline
\end{tabular}

Tabel 4. Penilaian Informasi dan Komunikasi

\begin{tabular}{|l|c|c|l|}
\hline $\begin{array}{l}\text { Informasi dan } \\
\text { Komunikasi }\end{array}$ & Sudah & Belum & \multicolumn{1}{|c|}{ Keterangan } \\
\hline $\begin{array}{l}\text { Organisasi memperoleh atau } \\
\text { menghasilkan dan } \\
\text { menggunakan informasi } \\
\text { yang berkualitas dan yang } \\
\text { relevan untuk mendukung } \\
\text { fungsi pengendalian internal }\end{array}$ & & $\checkmark$ & $\begin{array}{l}\text { Informasi yang dihasilkan perusahaan masih belum } \\
\text { berkualitas dan relevan, dikernakan pembagian gaji } \\
\text { karyawan yang masih dilakukan secara manual. } \\
\text { Sehingga informasi mengenai pembagian gaji pada } \\
\text { karyawan belum bisa di katakan berkualitas. }\end{array}$ \\
\hline $\begin{array}{l}\text { Organisasi berkomunikasi } \\
\text { dengan pihak eksternal } \\
\text { mengenai hal-hal yang } \\
\text { mempengaruhi fungsi } \\
\text { pengendalian internal. }\end{array}$ & $\checkmark$ & & $\begin{array}{l}\text { Perusahaan sangat memperhatikan informasi - } \\
\text { informasi yang berhubungan dengan pihak } \\
\text { eksternal khususnya kreditur untuk mengetahui } \\
\text { bagaimana informasi laporan keuangan perusahaan. }\end{array}$ \\
\hline
\end{tabular}

Tabel 5. Penilaian Pemantauan

\begin{tabular}{|l|c|c|l|}
\hline Pemantauan & Sudah & Belum & \multicolumn{1}{|c|}{ Keterangan } \\
\hline $\begin{array}{l}\text { Oraganisasi - organisasi memilih, } \\
\text { mengembangkan dan melakukan } \\
\text { evaluasi berkelanjutan dan/atau } \\
\text { terpisah untuk meyakinkan apakah } \\
\text { komponen pengendalian internal } \\
\text { yang hadir berfungsi. }\end{array}$ & $\checkmark$ & & $\begin{array}{l}\text { Perusahaan sudah melakukan proses } \\
\text { pemilihan, pengembangan dan evaluasi } \\
\text { secara berkelanjutan mengenai komponen - } \\
\text { komponen pengendalian internal. Evaluasi } \\
\text { dilakukan langsung oleh pimpinan } \\
\text { perusahaan untuk meyakinkan bahwa } \\
\text { karyawan melakukan tugas dan fungsi } \\
\text { mereka dengan baik. Misalnya pada } \\
\text { pembagian gaji, pemilik yang langsung } \\
\text { memeriksa dan memantau proses } \\
\text { pembagian gaji. }\end{array}$ \\
\hline
\end{tabular}




\section{Kesimpulan}

\section{PENUTUP}

Pengendalian intern pada siklus penggajian berdasarkan lima komponen pengendalian internal ternyata masih terdapat komponen yang belum menerapkan prinsip -prinsip komponen COSO secara lengkap atau masih di katakan belum efesien dan masih terdapat banyak kelemahan yaitu :

1. Dimana perusahaan masih terdapat fungsi dan tugas serta wewenang yang masih belum jelas. Karena belum adanya pemisahan tugas yang jelas antara fungsi pembuat daftar gaji dan fungsi pembayaran gaji, semuanya itu masih dikerjakan oleh satu bagian saja yaitu bagian keuangan. Sehingga bisa saja terjadi kecurangan atau penyalahgunaan data akuntansi.

2. Informasi dan komunikasi pada perusahaan masih belum berkualitas karena proses penggajian yang dilakukan perusahaan masih manual, sehingga seringkali informasi dan data yang disajikan menjadi kurang teliti.

Saran

1. PT. Anekaloka Indotuna sebaiknya membuat fungsi dan tugas dalam siklus penggajian secara tepat dan jelas. Misalnya melakukan pemisahan fungsi dan tugas pada bagian keuangan, adanya pemisahan tugas antara pembuat daftar gaji dengan pembagian gaji.

2. Perusahan sebaiknya menambahkan karyawan pada bagian keuangan untuk mempermudah aktivitas pengendalian pada proses penggajian.

3. Ada baiknya jika perusahaan terus mengikuti setiap perkembangan sistem kemajuan ilmu teknologi yang ada. Sehingga boleh meningkatkan pengendalian intern pada siklus penggajian menjadi lebih baik.

\section{DAFTAR PUSTAKA}

Azhar, Susanto. 2013. Sistem Informasi Akuntansi. Lingga Jaya. Bandung

Bahati, Alfred. 2014. Impact Of Computerised Accounting System On Performance Of Payroll Accounting: A Case of Urban Water Supply and Sewerage: Authorities. Journal of Administration Of The Open University Of Tanzania.

Basirun, Abdul. 2010. Jenis - jenis Penelitian. Gombong, Jawa Tengah.

Damayanti, Novia. 2015. Evaluasi Efektivitas Pengendalian Intern Atas Sistem Penggajian dan Pengupahan (Studi Kasus Pada PT. Karyamitra Budisentosa Pandaan-Pasuruan). Universitas Brawijaya Malang.

http://search.snapdo.com/?category=Web\&p=1\&st=ds\&ic=1\&q=Evaluasi+efektivitas+penge ndalian+intern+atas+sistem+penggajian+dan+pengupahan+pdf

Heryanto, Fede. 2014. Evaluasi Penerapan Pengendalian Internal Atas Siklus Penggajan pada PT. Jaya Kencana. Universitas Brawijaya Malang.

Mulyadi. 2015. Sistem Akuntansi. Jakarta: Salemba Empat.

Nayla, Akifa. 2014. Panduan Lengkap Sistem Administrasi Gaji dan Upah. Jakarta : Laksana.

Pontoh, Winston. 2013. Akuntansi Konsep dan Aplikasi. Manado : Halaman Moeka Publishing.

Pratiwi, Triani 2014. Pengaruh Pengendalian Internal Terhadap Efektifitas Pembiayaan Mudharabah Pada Bank Syariah. Universitas Widyatama Bandung.

Soeratno, Lincoln. 2008. Metodologi Penelitian Untuk Ekonomi dan Bisnis. Edisi Revisi. UPP STIM YKPN, Yogyakarta 